\title{
Consumers' Perception About Genetically Modified Foods and Their Purchase Intention in the City Center of Hatay, Turkey
}

\author{
Ahmet Duran Çelik*, Erdal Dağıstan \\ Department of Agricultural Economics, Faculty of Agriculture, Mustafa Kemal University, 3100 Hatay, Turkey
}

\section{A R T I C L E IN F O}

Article history:

Received 30 May 2016

Accepted 10 November 2016

Available online, ISSN: 2148-127X

Keywords:

Genetically Modified Food

Purchase Intention

Perception

Hatay

Awarness

\begin{tabular}{l} 
*Corresponding Author: \\
\hline E-mail: adcelik@mku.edu.tr
\end{tabular}

A B S T R A C T

In this study consumers' perception of, and purchase intention for genetically modified foods were examined in the city center of Hatay. The data of the 343 surveys were collected by using the face to face interview method. The data were analyzed by means of Likert Scale, and Spearman Correlation Analysis. According to the survey results, consumers' risk perceptions about genetically modified foods are quite high. Consumers don't willingly purchase genetically modified foods, and they intend to consume foods grown in traditional methods. High risk perceptions have a determining role on consumers' views about genetically modified foods and their purchase intention for them. Another outcome from this study is that consumers' awareness and knowledge levels about genetically modified foods are quite low, and that their perceptions and attitudes are mostly based on biases.

Türk Tarım - Gıda Bilim ve Teknoloji Dergisi, 4(11): 952-956, 2016

\section{Hatay İli Merkezinde, Tüketicilerin Genetiği Değiştirilmiş Ürünler Hakkında Algı ve Satınalma Gönüllülüklerinin Tespit Edilmesi}

\section{A K A L E B İ L G İ S İ}

Geliş 30 Mayıs 2016

Kabul 10 Kasım 2016

Çevrimiçi baskı, ISSN: 2148-127X

Anahtar Kelimeler:
Genetiği Değiştirilmiş Ürün
Satınalma Gönüllülüğü
Alg1
Hatay
Farkındalık
"Sorumlu Yazar:
E-mail: adcelik@mku.edu.tr

\section{Ö Z E T}

Bu çalışmada, Hatay ili merkezinde yaşayan tüketicilerin genetiği değiştirilmiş ürünler hakkındaki algıları ve satın alma gönüllülükleri incelenmiştir. Çalışmanın ana materyali, yüz yüze görüşme yöntemi ile 343 tüketiciden elde edilen verilerden oluşmaktadır. Veriler, liket ölçeği ve korelasyon analizi ile analiz edilmiştir. Araştırma sonuçlarına göre, tüketicilerin genetiği değiştirilmiş ürünler hakkındaki risk algılarının oldukça yüksek olduğu sonucuna ulaşılmıştır. Tüketiciler genetiği değiştirilmiş ürünleri satın almaya gönüllü olmayıp, geleneksel yollarla yetiştirilen ürünleri tüketmek istemektedirler. Yüksek risk algısı, tüketicilerin genetiği değiştirilmiş ürünlerle ilgili bakış açıları ve satın alma gönüllülükleri üzerinde belirleyici rol oynamaktadır. Çalışmadan ayrıca, tüketicilerin genetiği değiştirilmiş ürünler hakkındaki farkındalık ve bilgi seviyelerinin oldukça düşük olduğu, alg1 ve yaklaşımlarının çoğunlukla ön yargılar üzerine kurulu olduğu sonucuna ulaşı1mıştır.

\section{Introduction}

Genetically modified organisms are the fastest developing and adopting products among other cropping technologies. By 1996, GM products started to grow worldwide in an area totaling 1.7 million hectares; this number has increased 100 times in 18 years, and reached 175.2 million hectares by 2013. The United States is the biggest GM product grower with 70.1 million hectares. Along with Brazil, Argentina, Canada, and Paraguay; America is holding $87 \%$ of the GM product growth in the world. The number of GM product growers is 18 million, and 16.5 million producers consist of small farmers from different developing countries (James, 2013). The growth of GM products is prohibited in Turkey, and no GM products are permitted to be imported as food. However, there are few products which are allowed to be imported for the use of animal feed (Anonymous, 2014).

GM products have some benefits such as: enhancing plants' resistance to pests and diseases, increasing products' nutritional content, extending the products's shelf life (Lessick et al., 2002), and decreasing the usage of agricultural pesticides (James, 2013). On the other hand, GM products have some potential disadvantages 
like the possibility of leading to some diseases in the future and threating ecosystems by wiping out natural species (Lessick et al., 2002).

Worldwide research shows that there are significant differences in consumers' behaviors and perceptions about GM products in different countries. While some consumers have a positive view about GM foods in US (Hefferanan et al., 2002), european consumers have the opposite opinion and refuse to consume GM products (Bredahl, 2001; Magnusson and Hursti, 2002). Trust in their governments is one of the major determinants of consumer's positive attitudes about GM food in the US (Costa-Font et al., 2008), and trust in authorities effects consumer's risk perception (Siegrist and Cvekovich, 2000). Another determinant of consumer risk perception is the effect of the media. Differences in media reporting effect consumers attitutes and risk perception toward GM foods (Vilella-Vila and Costa-Font, 2008). Positive media increases consumers' acceptance about GM foods in the US and China (Curtis et al., 2004). Information about the benefits of biotechnology is another factor over consumers' acceptance of GM foods. Consumers who have information on GM products' potential benefits approach GM foods positively (Lusk et al., 2004; Hossain et al., 2003).

Consumer perception about GM foods is mostly negative in Turkey. Demir and Pala (2007) found that $86 \%$ of consumers were not intending to pay for GM foods; however, consumer perceptions were affected positively along with a hightened level of knowledge. Mehmetoğlu (2007) found that only $8 \%$ of consumers considered GM foods safe and the rest of the consumers thought that GM foods were risky. Oğuz (2009) found that consumers' risk perception about GM foods were quite high, and sociodemographic attributes had no influnce over consumers' behavior about GM foods. In a study, Koçak et al. (2010) presented that $72 \%$ of medical students did not have sufficient knowledge about GM products. In a countrywide study that was conducted by Haspolat Kaya (2013), it was found that $84 \%$ of consumers were not willing to purchase GM products.

The purpose of this study was determining consumers' perception about GM foods and the effect of this perception on purchase intention, in the city center of Hatay in Turkey. Lack of research about consumer behaviour and perception reguarding GM products in this region is the reason for this study.

\section{Material and Method}

\section{Material}

The main material of the study was based on primary data that was obtained by face-to-face interviews from consumers in the city center of Hatay in 2013. Secondary data was obtained from a variety of previous studies.

\section{Method}

Determining the bulk sample and data collection: The research area consisted of consumers who were living in the city center of Hatay. Simple random sampling was used in the research. The sampling formula that was used to determine the sample size is as below (Churchill, 1995). In the sampling, $P$ and $Q$ values were determined as 0.50 . Accordingly, sample size was 384 at a $95 \%$ level of significance and at a 5\% error margin.

$$
n=\left(\frac{Z_{x / 2}}{d}\right)^{2} P \cdot Q
$$

$\mathrm{P} \quad=$ Positive probability $(50 \%)$

$\mathrm{Q} \quad=1-\mathrm{P}$ Negative probability

$Z_{x / 2}=$ Confidence interval (\%95, table value 1.96$)$

$d \quad=$ Error margin $(\% 5)$

$$
n=\left(\frac{1.96}{0.05}\right)^{2} 0.05 * 0.05 \cong 384
$$

Under the research 384 surveys were carried out; however, some surveys were excluded due to inadequate data resulting in the evaluation of 343 surveys. The data of the 343 surveys were collected by using the face to face interview method in the city center of Hatay.

Data evaluation: Spearman rank correlation coefficient and likert scale were used to evaluate data in this study. Correlation analysis is a statistical analysis method to evaluate the relationship between two variables. Spearman rank correlation coefficient is used often in marketing research and is a highly effective method to evaluate non-parametric data. The formula to evaluate spearman rank correlation is as below. Correlation coefficient that is approaching +1 indicates a positive and strong relationship, 0 correlation coefficient indicates there is no statistical relationship and approaching -1 indicates a negative and strong relationship (Jobson, 1991; Nakip, 2006). Values between 0.00 and 0.25 indicate a very poor relation, between 0.26 and 0.49 indicate a poor relation, between 0.50 and 0.69 indicate a medium relation, between 0.70 and 0.89 indicate a strong relation, and values between 0.90 and 1.00 indicate a very strong relation (Kalayc1, 2009).

$$
r=1-\frac{6\left(\sum d^{2}\right)}{n\left(n^{2}-1\right)}
$$

Likert scale is used to determine consumer opinions about a specific statement which presents the level of agreement or disagreement about the statement. There are different kinds of likert scales such as; 5 point likert scale, 7 point likert scale or 9 point likert scale (Karagöz et al., 2004). The 5 point likert scale was used in this study to evaluate consumers' level of agreement or disagreement about statements; the statements were ranged from a negative statement to a positive statement (1=low, $5=$ high).

\section{Results and Discussion}

Demographic characteristics about consumers are presented in Table 1. Under the research, participants' gender distribution was $57 \%$ male and $43 \%$ female. According to the statistics from the Turkish Statistical Institute (TÜIK), gender distribution in the city center of Hatay in 2013 was $51 \%$ male and $49 \%$ female which was close to the distribution in this study (TÜIK, 2014).

In the range of age groups, the majority was between 
26 and 45 years old and the share of these groups was $55 \%$ among all of the consumers. Approximately half of the consumers were university graduates which included associate and undergraduates. Most of the consumers' family sizes $(62 \%)$ consisted of between 4 and 6 people. According to the TÜIKK statistics, the average family size in the city center of Hatay was 4.14 persons in 2013 (TÜİK, 2014) which matched the findings in this research. Four groups were taken into consideration to determine consumer monthly income and it was found that $53 \%$ of the consumers' monthly income was between 1000 and 2999 Turkish Liras (TL), and 38\% of the consumers' monthly food expenses were between 250 and 499 TL; nevertheless, $80 \%$ of the consumers' monthly food expenses were below 1000 TL.

Soybean, corn, cotton, and canola are the four major GM products produced in the world (James, 2013). The names of these four products were asked about in order to determine consumers' knowledge about GM products. Under the research, it was found that $50 \%$ of the consumers didn't know any of these four major GM products; $25 \%$ of the consumers knew only one of the four major products and only $25 \%$ of the consumers knew more than one product's name. In light of this finding, it could be said that consumers' specific knowledge about GM products' names were very limited.

According to the research findings, $52 \%$ of the consumers considered GM products to be hormoneinjected products, and only $34 \%$ of the consumers were aware of the difference between GM products and hormone-injected products.
Media was found to be consumers' major information source about GM products, and the rate of following scientific sources such as conferences were found to be very low (8\%). Similar findings were found in different studies which were carried out by Mehmetoğlu (2007) and Ayaz et.al. (2011) that consumers' knowledge about GM products is limited by TV programs. Therefore, it was found out that consumers were not reached by sufficient scientific information about GM products.

Consumers' level of risk perception, levels of awareness and knowledge, and purchase intentions are presented in table 2. Consumers' awareness and knowledge levels about GM products were evaluated by Q1, Q2, Q3 and Q4. Risk perception was determined by Q5, purchase intention was determined by Q6. Consumers' willingness to consume traditional products was determined by Q7, and Q8 was used to determine consumers's benefit perception of GM products.

Q1: GM products are more resistant to pests and diseases

Q2: GM products have a longer shelf life

Q3: GM products are cheaper than regular products GMOs

Q4: Products' nutrition amount can be enriched by

Q5: How risky do you think GM products are for human health?

Q6: Would you purchase GM products?

Q7: I only consume products which are grown in traditional methods

Q8: What does GM product mean to you (beneficial or not beneficial)?

Table 1 Consumer demographic characteristics and their distributions (1\$=2TL, 2013)

\begin{tabular}{|c|c|c|c|}
\hline Variables & Explanation & Frequency & Ratio (\%) \\
\hline \multirow{2}{*}{ Gender } & Male & 195 & 56.85 \\
\hline & Female & 148 & 43.15 \\
\hline \multirow{6}{*}{ Age } & $16-25$ & 60 & 17.49 \\
\hline & $26-35$ & 96 & 27.99 \\
\hline & $36-45$ & 95 & 27.70 \\
\hline & $46-55$ & 69 & 20.12 \\
\hline & $56-65$ & 16 & 4.66 \\
\hline & $66+$ & 7 & 2.04 \\
\hline \multirow{5}{*}{ Education } & Primary & 38 & 11.08 \\
\hline & Middle School & 33 & 9.62 \\
\hline & High school & 83 & 24.20 \\
\hline & Associate and undergraduates & 170 & 49.56 \\
\hline & Postgraduates & 19 & 5.54 \\
\hline \multirow{4}{*}{ Family Size } & $1-3$ & 97 & 28.28 \\
\hline & $4-6$ & 211 & 61.52 \\
\hline & $7-9$ & 26 & 7.58 \\
\hline & $10+$ & 9 & 2.62 \\
\hline \multirow{4}{*}{ Income (Monthly) } & $<1000 \mathrm{TL}$ & 38 & 11.8 \\
\hline & $1000-2999 \mathrm{TL}$ & 182 & 53.06 \\
\hline & $3000-4999 \mathrm{TL}$ & 82 & 23.91 \\
\hline & $5000 \mathrm{TL}-<$ & 41 & 11.95 \\
\hline \multirow{5}{*}{ Monthly Food Expense } & $<250 \mathrm{TL}$ & 28 & 8.16 \\
\hline & 250 TL-499 TL & 129 & 37.61 \\
\hline & 500 TL-999 TL & 114 & 33.24 \\
\hline & 1000 TL-1499 TL & 46 & 13.41 \\
\hline & $1500 \mathrm{TL}-<$ & 26 & 7.58 \\
\hline
\end{tabular}


Table 2 Consumers' answer distribution about GM products

\begin{tabular}{|c|c|c|c|c|c|c|c|c|}
\hline \multirow{2}{*}{ Variables } & \multicolumn{5}{|c|}{$\begin{array}{c}\text { Scale }(\%) \\
0\end{array}$} & \multicolumn{3}{|c|}{ Descriptive Statistics } \\
\hline & 1 & 2 & 3 & 4 & 5 & Mean & Std. Deviation & Variance \\
\hline Q1 & 10.5 & 22.7 & 38.2 & 22.4 & 6.2 & 2.91 & 1.054 & 1.112 \\
\hline Q2 & 6.1 & 19.5 & 23.3 & 40.8 & 10.3 & 3.29 & 1.083 & 1.173 \\
\hline Q3 & 7.6 & 19.8 & 34.7 & 28.6 & 9.3 & 3.12 & 1.072 & 1.149 \\
\hline Q4 & 15.5 & 31.5 & 26.8 & 22.4 & 3.8 & 2.68 & 1.099 & 1.208 \\
\hline Q5 & 37.3 & 51.9 & 9.9 & 0.9 & 0.0 & 1.74 & 0.666 & 0.444 \\
\hline Q6 & 12.5 & 46.4 & 25.1 & 14.9 & 1.2 & 2.46 & 0.932 & 0.869 \\
\hline Q7 & 4.1 & 8.7 & 9.3 & 49.6 & 28.3 & 3.89 & 1.042 & 1.085 \\
\hline Q8 & 24.5 & 58.0 & 16.9 & 0.3 & 0.3 & 1.94 & 0.670 & 0.449 \\
\hline
\end{tabular}

Table 3 Correlation coefficient between variables and their significance levels

\begin{tabular}{|c|c|c|c|c|}
\hline Variables & Test & $\begin{array}{c}\text { Benefit Perception } \\
\text { of GM Product }\end{array}$ & $\begin{array}{l}\text { Risk Perception } \\
\text { of GM Product }\end{array}$ & $\begin{array}{l}\text { Purchase } \\
\text { Intention }\end{array}$ \\
\hline \multirow{3}{*}{$\begin{array}{l}\text { Benefit Perception of } \\
\text { GM Product }\end{array}$} & Correlation Coefficient & & -0.521 & 0.460 \\
\hline & Significance Level & & 0.000 & 0.000 \\
\hline & $\mathrm{N}$ & & 343 & 343 \\
\hline \multirow{3}{*}{$\begin{array}{l}\text { Risk Perception of } \\
\text { GM Product }\end{array}$} & Correlation Coefficient & -0.521 & & -0.326 \\
\hline & Significance Level & 0.000 & & 0.000 \\
\hline & $\mathrm{N}$ & 343 & & 343 \\
\hline \multirow{3}{*}{ Purchase Intention } & Correlation Coefficient & 0.460 & -0.326 & \\
\hline & Significance Level & 0.000 & 0.000 & \\
\hline & $\mathrm{N}$ & 343 & 343 & \\
\hline
\end{tabular}

According to the research results, only $29 \%$ of the consumers were aware that GM products were more resistant to pests and diseases (Q1), almost $51 \%$ of the consumers were aware that it was possible to extend products' shelf life with gene transfer (Q2). While 38\% of the consumers were thinking that GM products are cheaper than regular products (Q3), only $26 \%$ of them were aware of the possibility to enrich products' nutrition amount due to GMOs (Q4). According to these results, it is seen that consumer awareness levels about the potential benefits of GM products were very low.

Consumer risk perception about GM products was found quite high. While $89 \%$ of consumers were thinking that GM products are risky for human health, only $1 \%$ were thinking that GM products are not risky for human health, and $10 \%$ of them had no opinion (Q5). This result shows that the consumer risk perception about GM products was very high. A similar result was found in another study that was carried out by Oğuz (2009).

Research results indicate that most of the consumers were not intending to purchase GM products; only $16 \%$ of the consumers intended to purchase GM products, $59 \%$ of the consumers refused to purchase GM products, and $25 \%$ of the consumers had no opinion (Q6). In a study which was carried out by Kaya (2013), consumer purchase intention about GM products was also found very low.

The majority of the consumers $(78 \%)$ only intend to consume products grown in traditional ways (Q7). Most of the consumers prefer naturally grown products instead of consuming GM products, and they are prejudiced about new production technologies.

Consumers' benefit perceptions about GM foods were mostly found negative (Q8). While $82 \%$ of them were thinking that GM products are not beneficial, only less than $1 \%$ of them had positive opinion about it, and $17 \%$ of the consumers viewed GM products the same as any other products

Correlation coefficients about consumers' benefit perception of GM products, GM product risk perception, and purchase intention are shown in Table 3. A negative directional correlation was found between GM products' risk perception and purchase intention, this correlation indicates that consumer purchase intention decreases along with an increase in their risk perception about GM products.

Consumer risk perception about GM products explains $33 \%$ of their purchase intention. In a study which was carried out by Harrison et.al (2004) in US and Italy, it was found that consumer purchase intention was affected negatively by their risk perception about GM products. A positive directional correlation was found between consumer GM product benefit perception and purchase intention. It could be said that a positive consumer perception about GM products also affects their purchase intention positively. Consumer benefit perception about GM products explains $46 \%$ of consumer purchase intention. Finally, a negative correlation was found between GM product risk perception and GM product benefit perception. According to this result, an increase in consumer risk perception shapes their GM product benefit perception negatively. In a study which was carried out by Costa-Font et al. (2007), risk and benefit perceptions about GM foods were also found to be dependent.

\section{Conclusions}

As a fast growing technology, biotechnology and GM products contain many question marks as well as potential benefits, and this technology arouses anxiety about it going out of control and causing irreversible damage in the future. Both, being a new technology and having unpredictable effects in the future, make consumers 
suspicious about biotechnology and its products.

In this study that was carried out in the city center of Hatay, independently of demographic characteristics; high consumer risk perception and low benefit perception were found about GM products. Accordingly, consumers view GM products as harmful products and they don't intend to consume these products. However, this behaviour is not based on knowledge, consumer perception is mostly formed around biases. Furthermore, the rate of following scientific sources such as scientific conferences and books are limited, and TV was found as the main information source about GM products. Another important finding from this study was that consumers showed a traditionalist approach about food products and they intend to consume products which are grown in traditional ways.

\section{Acknowledgements}

This study was prepared by using the data from the MSc thesis which is titled "Consumers' perception about genetically modified foods and effects on their purchase intention".

\section{References}

Anonymous. 2014. Besd-Bir, Piliç Eti Sektör Raporu, 64.

Ayaz A, Bilici S, Uyar MF, Ay B, Börekci S, Kök E. 2011. Consumer Acceptance, Knowledge and Attitudes Towards Organic and Genetically Modified Foods: a Cross-Sectional Study Among Turkish University Students. HealthMED, 5(5): 1014-1021.

Bredahl L. 2001. Determinants of Consumer Attitudes and Purchase Intentions With Regard to Genetically Modified Foods - Results of a Cross-National Survey. Journal of Consumer Policy (24): 23-61.

Churchill GA. 1995. Marketing Research: Methodologial Foundations, The Dryden Press, Harcourt Brace College Publishers, Sixth Edition.

Curtis KR, McCluskey JJ, Wahl TI. 2004. Consumer Acceptance of Genetically Modified Food Products in the Developing World. AgBioForum, 7(1\&2): 70-75.

Costa-Font J, Mossialos E. 2007. Are perceptions of risks and benefits of genetically modified food (in)dependent?. Food Quality and Preference, 18: 173-182.

Costa-Font M, Gil JM, Traill WB. 2008. Consumer acceptance, valuation of and attitudes towards genetically modified food: Review and implications for food policy. Food Policy 33: 99-111.

Demir A, Pala A. 2007. Genetiği Değiştirilmiş Organizmalara Toplumun Bakış Açısı. Hayvansal Üretim 48(1): 33-43.

Harrison RW, Boccaletti S, House L. 2004. Risk Perceptions of Urban Italian and United States Consumers for Genetically Modified Foods. AgBioForum, 7(4): 195-201.
Haspolat KI. 2013. Alteration of Attitude toward GM-Foods of Urban Consumer Depending Geographical Regions in Turkey. International Journal of Chemical, Environmental \& Biological Sciences (IJCEBS) 1(1): 47-50.

Hefferanan JW, Hillers VN. 2002. Attitudes of Consumers Living in Washington Regarding Food Biotechnology. Journal of the American Dietetic Association 102(1): 85-88.

Hossain F, Onyango B, Schilling B, Hallman W, Adelaja A. 2003. Product Attributes, Consumer Benefits and Public Approval of Genetically Modified Foods. International Journal of Consumer Studies, 27(5): 353-365.

James C. 2013. Brief 46: Global Status of Commercialized Biotech/GM Crops: 2013. Executive Summary. International Service for the Acquisition of Agri-biotech Applications (ISAAA), 1-13.

Kalaycı Ş. 2009. SPSS Uygulamalı Çok Değişkenli İstatistik Teknikleri (4. Bask1). Ankara: Asil Yayın Dağıtım Ltd.Şti.

Karagöz Y, Ekici S. 2004. Sosyal Bilimlerde Yapilan Uygulamalı Araştırmalarda Kullanılan İstatistiksel Teknikler ve Ölçekler. C.Ü. İktisadi ve İdari Bilimler Dergisi, 5(1): 25-43.

Koçak N, Türker T, Kılıç S, Hasde M. 2010. Tıp Fakültesi Öğrencilerinin Genetiği Değiştirilmiş Organizmalar Hakkındaki Bilgi, Tutum ve Davranışlarının Belirlenmesi. Gülhane Tıp Dergisi 2010; 52: 198-204.

Lessick M, Keithley J, Swanson B, Lemon B. 2002. Genetically modified foods: a taste of the future. Medsurg Nursing 11: 242-246.

Lusk JL, House LO, Valli C, Jaeger SR, Moore M, Morrow JL, Traill WB. 2004. Effect of information about benefits of biotechnology on consumer acceptance of genetically modified food: evidence from experimental auctions in the United States, England, and France. European Review of Agricultural Economics, 31 (2): 179-204.

Magnusson MK, Hursti UK. 2002. Consumer Attitudes Towards Genetically Modified Foods. Appetite. 39: 9-24.

Mehmetoglu AC. 2007. Preferences of Turkish people for irradiated, GM or organic foods. Journal of Food, Agriculture \& Environment Vol.5 (3\&4): 7 4-8 0.

Nakip M. 2006. Pazarlama Araştırmaları. Ankara: Seçkin Yayıncilik.

Oğuz Ö. 2009. Attitudes of consumers toward the effects of genetically modified organisms (GMOs): The example of Turkey. Journal of Food, Agriculture \& Environment Vol.7 (3\&4): 15 9-1 65.

Siegrist M, Cvekovich G. 2000. Perception of Hazards: The Role of Social Trust and Knowledge. Risk Analysis, 20(5): 713-719.

TÜİK. 2014. Tarım İstatistikleri Veri tabanı. Turkish Statistical Institute, Ankara. (The date accessed: 05.12.2014). Available at: http://www.tuik.gov.tr/ilGostergeleri/iller/ HATAY.pdf

Vilella-Vila M, Costa-Font J. 2008. Press Media Reporting Effects on Risk Perceptions and Attitudes Towards Genetically Modified (GM) Food. The Journal of SocioEconomics 37: 2095-2106 